\title{
An Analytical Approach for Removal of Heavy Metals from Aqueous Solutions by Inorganic Basic Lead Molybdate Ion Exchanger 8-Hydroxyquinoline
}

\author{
UPASANA SHARMA $^{1}$, SANGEETA AGRAWAL ${ }^{2}$ and RAKESH SHRIVASTAV ${ }^{3}$ \\ ${ }^{1,2}$ Department of Chemistry, S.S.V (P.G) College, Hapur, India \\ ${ }^{3}$ Department of Chemistry, NGF College of Engineering \& Technology, \\ Palwal, 121105, India \\ srivastavrakesh@gmail.com
}

Received 29 May 2013 / Accepted 10 July 2013

\begin{abstract}
The present paper deals with the synthesis, ion exchange properties and analytical applications of basic lead molybdate as a new inorganic ion-exchanger. A simplified synthesis and physicochemical properties which show that the chelating resin $\mathrm{HQCR}_{4}$ in $\mathrm{H}^{+}$behaves as a weak cation exchanger. The results of rate of sorption experiments reveal that the rate of sorption is high during the initial period of contract time and time required for maximum sorption capacity is $50 \mathrm{~min}$. The sorption capacities determined for six metal ions in three $\mathrm{pH}$ systems resulted the following order. $\mathrm{Hg}^{2+}>\mathrm{Co}^{2+}$ $>\mathrm{Cd}^{2+}>\mathrm{Zn}^{2+}>\mathrm{Ni}^{2+}>\mathrm{Cu}^{2+}$. The results of distribution coefficients determined for thirteen metal ions in different $\mathrm{pH}$ system indicate that $\mathrm{Hg}^{2+} \mathrm{Cu}^{2+}$ and $\mathrm{Fe}^{3+}$ are strongly adsorbed on $\mathrm{HQCR}_{4}$ resign $\mathrm{Th}^{4+}$, $\mathrm{Zn}_{2+}, \mathrm{Co}^{2+}$ and $\mathrm{Ni}^{2+}$ only partially while $\mathrm{Cd}^{2+} \mathrm{Mn}^{2+}$ and $\mathrm{Zr}$.
\end{abstract}

Keywords: Catechol - formaldehyde copolymer, 8-Hydroxyquinoline, Separation, Metal ions

\section{Introduction}

8-Hydroxyquinoline (8-HQ) forms chelate compounds with a number of metal ions. Chromatography on 8-hydroxyquinoline with metal ions can permit differentiation of various ions by stability and colour of the metal complex formed. Its incorporation in a resin matrix was therefore, deemed of interest in connection with separation and extraction of metal ions. Chelating resins have many practical applications in separation, preconcentration, water treatment, environmental protection etc.

The synthesis and application of chelating resins have been reviewed recently ${ }^{1-14}$. The chelating resins are assumed to form chelate rings in the sorbent phase during the sorption of metals ${ }^{15}$. The possibility of forming chelate ring in the sorbent phase is affected by different factors such as the nature of the chemically active group capable of complexation, the physical nature of the polymeric matrix, steric factors, sorption conditions etc. This chapter deals with the synthesis of catechol formaldehyde based resin containing 8-hydroxyquinoline as functional groups. 
The sorption behavior of resin towards various metal ions, distribution coefficients, the sorption and influence of $\mathrm{pH}$ on metal uptake has been investigated.

\section{Experimental}

Catechol, formaldehyde and 8-hydroxyquinoline (BDH, India) were used. All other reagents were of AR grade and prepared in double distilled water.

\section{Apparatus}

An electric rotary shaking machine were used for shaking and UV-Visible spectrophotometer (Carry 100, Conc Varian) and Schimadzu 8201PC spectrophotometric measurements and IR analysis was carried out on Chemito IR spectrophotometer. The $\mathrm{pH}$ change during the experiments was observed by pH meter(WTW 540 GLP). Brunauer-Emmett-Teller surface area (BET) measurement was conducted using Micro metrics adsorption equipment (ASAP 2010) determining the nitrogen (99.99\% purity) as the analysis gas. The powdered catalyst samples were overnight placed in the oven at $110{ }^{\circ} \mathrm{C}$ in order to remove the moisture, degasified the sample followed by the analysis of surface area by heating to $350{ }^{0} \mathrm{C}$ for 4 hours under Nitrogen atmosphere.

\section{Preparation of 8-hydroxyquinoline chelating resin $\left(\mathrm{HQCR}_{4}\right)$}

The 8-hydroxyquinoline chelating resins were prepared by mixing catechol, formaldehyde and 8-hydroxyquinoline in the presence of hydrochloric acid as a catalyst. The details of the conditions of synthesis of chelating resins are given in the Table 1 . The reaction mixture was refluxed for $12 \mathrm{~h}$ in a round bottom flask and the separated resinous product was washed with demineralized water (DMW) to remove the unreacted reagents. The resin was dried at $60 \pm 2{ }^{\circ} \mathrm{C}$ in vacuum oven. The $60-100$ mesh fraction of the resin was used for the metal sorption studies.

\section{Rate of sorption}

The rate of sorption was studies by shaking $0.1 \mathrm{~g}$ of the chelating resin, $\left(\mathrm{HQCR}_{4}\right)$ with $20 \mathrm{~mL}$ of $5 \times 10^{-3} \mathrm{~mol} \mathrm{dm}^{-3}$ solution of metal ion. After different time intervals the contents of the flask were filtered used Whatman No.4 filter paper and the amount of unadsorbed metal ion was determined in the filtrate by EDTA titration.

\section{Sorption of metal ions by batch operation}

Sorption of metal ions was determined by batch operation unless other wise stated, the following method was applied. To a glass stoppered conical flask containing $100 \mathrm{mg}$ of resin and $18 \mathrm{~mL}$ of $1 \mathrm{~mol} \mathrm{~L}^{-1}$ acetate buffer ( $\mathrm{pH} \mathrm{3-7)}$ or hydrochloric acid $(\mathrm{pH} \mathrm{l,2})$ were added. When this mixture had been equilibrated $2 \mathrm{~mL}$ of metal ions solutions $\left(0.1 \mathrm{~mol} \mathrm{~L}^{-1}\right)$ was added to the conical flask, then the mixture was shaken at room temperature for $6 \mathrm{~h}$. The resin was filtered off on a glass wool and the amount of metal ions remaining in the filtrate was determined complex-metrically using EDTA.

\section{Breakthrough capacity}

The column technique permits a continuous operation which is much superior to batch process in respect of time and space. The breakthrough behavior of $\mathrm{Co}^{2}+, \mathrm{Zn}^{2}+$ and $\mathrm{Hg}^{2}+$ was investigated by passing $1 \times 10^{-3} \mathrm{~mol} \mathrm{dm}^{-3}$ solution of metal ion ( $\mathrm{pH} \sim 7$ ) through a glass column (i.d.4 mm) packed with $1 \mathrm{~g}$ of $\mathrm{HQCR}_{4}$. The flow rate was maintained $\sim 0.5 \mathrm{~mL} \mathrm{~min}^{-1}$. 


\section{Distribution studies}

The relative affinities of the chelating resin $\left(\mathrm{HQCR}_{4}\right)$ for 13 metal ions were studied by batch equilibrium method as mentioned above. The distribution coefficients ( $K_{d}$ values) were calculated from the following equation

$$
\mathrm{Kd}_{\left(\mathrm{mLg}^{-1}\right)}=\frac{\text { Amount of metal ion in the resin phase } \mathrm{g}^{-1}}{\text { Amount of metal ion in the solution phase } \mathrm{mL}^{-1}}
$$

\section{Infrared Studies}

The FTIR spectrum of the 8-hydroxyquinoline chelating resin sample $\mathrm{HQCR}_{4}$ was studied using $\mathrm{KBr}$ disc technique.

\section{Chromatographic separations}

The chelating resin $\mathrm{HQCR}_{4}$ in $\mathrm{H}^{+}$form was packed into a chromatographic glass tube (i.d. $0.5 \mathrm{~cm}$ ) to form a bed $10 \mathrm{~cm}$ in height. The sample solutions containing the desired metal ions having large difference in $\mathrm{K}_{\mathrm{d}}$ values were introduced into the column and eluted at flow rate $0.5 \mathrm{~mL} \mathrm{~min}^{-1}$ with suitable eluent.

\section{Results and Discussion}

The experimental conditions for the preparation of chelating resin samples by mixing catechol, formaldehyde and 8-hydroxyquinoline, yield of the products and sorption capacities are summarized in Table 1 . The physicochemical properties of 8-hydroxyquinoline chelating resin sample $\mathrm{HQCR}_{4}$ are given Table 2. In order to know the appropriate time required for the maximum adsorption of the metal ion on $\mathrm{HQCR}_{4}$ resin, the sorption capacity was determined by shaking the resin with the metal ion solution for different time intervals. The results of these experiments are plotted in Figure 1. The results of sorption capacities of $\mathrm{Zn}^{2+}, \mathrm{Cd}^{2+}, \mathrm{Hg}^{2+}$, $\mathrm{Cu}^{2+}, \mathrm{Ni}^{2+}$ and $\mathrm{Co}^{2+}$ on $\mathrm{HQCR}_{4}$ at different $\mathrm{pH}(2-6)$ are presented in Table 3. The distribution coefficients (Kd values) of 13 metal ions were determined by batch experiments in the $\mathrm{pH}$ range (1 -7). The observed Kd values are presented in Table 4 . The results of infrared spectrum of the chelating resin sample $\mathrm{HQCR}_{4}$ are plotted in Figure 2.

Table 1. Preparation of 8-hydroxyquinoline chelating resins $\left(\mathrm{HQCR}_{4}\right)$

\begin{tabular}{|c|c|c|c|c|c|c|}
\hline \multirow{2}{*}{$\begin{array}{l}\text { Resin } \\
\text { Sample }\end{array}$} & \multicolumn{3}{|c|}{ Mixing amounts } & \multirow{2}{*}{$\begin{array}{c}2 \mathrm{~N} \mathrm{HCl} \\
\mathrm{mL}\end{array}$} & \multirow{2}{*}{ Yield, g } & \multirow{2}{*}{$\begin{array}{c}\text { Sorption } \\
\text { capacity for } \mathrm{Cu}^{2+} \mathrm{mg}\end{array}$} \\
\hline & $\begin{array}{c}\mathrm{C}_{6} \mathrm{H}_{4}(\mathrm{OH})_{2} \\
\mathrm{~mol}\end{array}$ & $\begin{array}{c}\mathrm{HCHO} \\
\mathrm{mol}\end{array}$ & $\begin{array}{c}\text { 8-HQ } \\
\text { mol }\end{array}$ & & & \\
\hline $\mathrm{HQCR}_{0}$ & 0.10 & 0.10 & 0.00 & 10 & 1.20 & 18.4 \\
\hline $\mathrm{HQCR}_{1}$ & 0.10 & 0.10 & 0.05 & 10 & 1.90 & 28.5 \\
\hline $\mathrm{HQCR}_{2}$ & 0.1 & 0.10 & 0.10 & 10 & 2.60 & 35.6 \\
\hline $\mathrm{HQCR}_{3}$ & 0.1 & 0.20 & 0.05 & 10 & 2.00 & 28.9 \\
\hline $\mathrm{HQCR}_{4}$ & 0.1 & 0.20 & 0.10 & 10 & 2.78 & 36.4 \\
\hline
\end{tabular}

Table 2. Physicochemical properties of Resin $\left(\mathrm{HQCR}_{4}\right)$

\begin{tabular}{|c|c|}
\hline Properties & Result \\
\hline Moisture content, \% & 5.64 \\
\hline Solid, \% & 94.36 \\
\hline Void space fraction & 0.56 \\
\hline True density, $\mathrm{g} \mathrm{mL}^{-1}$ & 1.10 \\
\hline Ion exchange capacity for $\mathrm{H}^{+} / \mathrm{Na}^{+}$exchange $\left(\mathrm{m} \mathrm{mol} \mathrm{g}^{-1}\right)$ dry resin & 0.20 \\
\hline
\end{tabular}




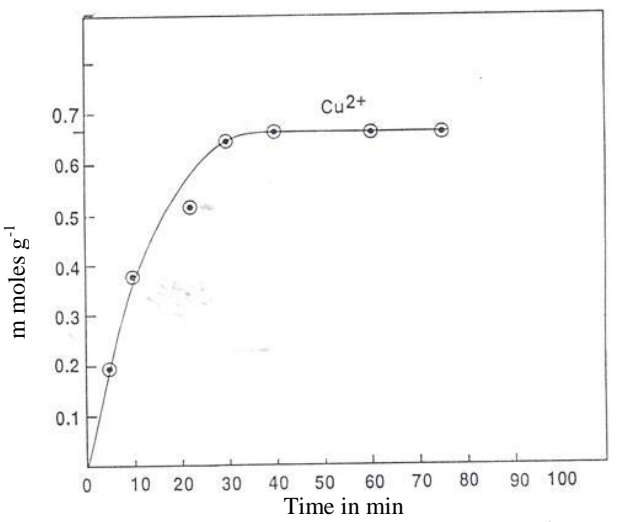

Figure 1. Rate of sorption of $\mathrm{Cu}^{2+}$

Table 3. Sorption capacity ( $\mathrm{mg} \mathrm{g}^{-1}$ ) of hydroxyquinoline chelating resin sample ( $\left.\mathrm{HQCR}_{4}\right)$ for different metal ions

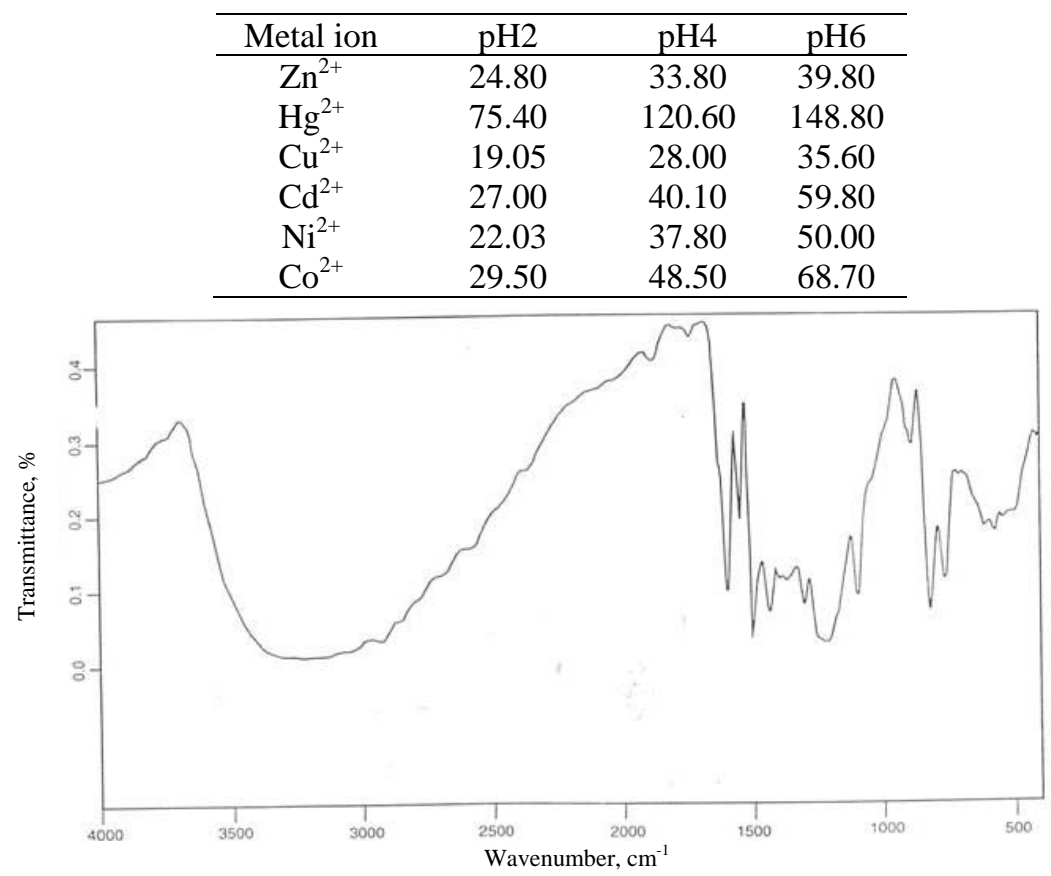

Figure 2. FTIR spectrum of chelating resin sample $\left(\mathrm{HQCR}_{4}\right)$

The result of break through experience investigated for $\mathrm{Co}^{2+}, \mathrm{Zn}^{2+}$ and $\mathrm{Hg}^{2+}$ are plotted in Figure 3. The quantitative separation of metal ions in their synthetic mixtures were tried on the column of $\mathrm{HQCR}_{4}$, based on the differences in Kd values. Those, achieved experimentally are summarized in Table 5. The percent error observed during these experiments is also given. The elution curves for the separations of $\mathrm{Pb}^{2+}-\mathrm{Zn}^{2+}, \mathrm{Pb}^{2+}-\mathrm{Th}^{4+}, \mathrm{Ni}^{2+}-\mathrm{Cu}^{2+}, \mathrm{Zr}^{4+}, \mathrm{Hg}^{2+} \mathrm{Al}^{3+}-$ $\mathrm{Fe}^{3+}, \mathrm{Ni}^{2+}-\mathrm{Co}^{2+}-\mathrm{Hg}^{2+}$ and $\mathrm{Cd}^{2+}-\mathrm{Zn}^{2+} \mathrm{Hg}^{2+}$ are plotted in Figure (4-10). Ion exchange capacity was determined by passing $1 \mathrm{~mol} \mathrm{dm}^{-3} \mathrm{NaCl}$ solution through a column of $\mathrm{HQCR}_{4}$ in $\mathrm{H}^{+}$form and titrating the eluted $\mathrm{H}^{+}$against a standard $\mathrm{NaOH}$ solution. 
Table 4. $\mathrm{K}_{\mathrm{d}}$ values of metal ions on $\left(\mathrm{HQCR}_{4}\right)$ at different $\mathrm{pH}$

\begin{tabular}{cccccccc}
\hline \multicolumn{2}{c}{ Metal } & & \multicolumn{4}{c}{$\mathrm{K}_{\mathrm{d}}$ values mL g } \\
\hline $\mathrm{Ion}$ & $\mathrm{pH} \mathrm{1}$ & $\mathrm{pH} \mathrm{2}$ & $\mathrm{pH} \mathrm{3}$ & $\mathrm{pH} \mathrm{4}$ & $\mathrm{pH}$ & $\mathrm{pH} \mathrm{6}$ & $\mathrm{pH} \mathrm{7}$ \\
\hline $\mathrm{Hg}^{2+}$ & 200.8 & 220.3 & 310.0 & 380.0 & 400.2 & 445.7 & 590.5 \\
$\mathrm{Cu}^{2+}$ & 155.2 & 208.0 & 280.1 & 344.1 & 392.3 & 410.8 & 427.3 \\
$\mathrm{Th}^{4+}$ & 68.0 & 100.0 & 104.2 & 115.0 & 182.4 & 200.4 & 261.1 \\
$\mathrm{Zn}^{2+}$ & 63.2 & 89.4 & 95.0 & 101.3 & 165.1 & 199.0 & 240.0 \\
$\mathrm{Co}^{2+}$ & 78.6 & 103.3 & 140.0 & 206.7 & 218.0 & 256.5 & 388.1 \\
$\mathrm{Ni}^{2+}$ & 20.2 & 35.8 & 59.6 & 70.4 & 73.6 & 88.8 & 100.1 \\
$\mathrm{Cd}^{2+}$ & 16.4 & 28.2 & 31.0 & 35.4 & 42.0 & 62.5 & 102.0 \\
$\mathrm{Mn}^{2+}$ & 13.0 & 20.8 & 24.3 & 29.4 & 34.0 & 38.6 & 48.6 \\
$\mathrm{Zr}^{4+}$ & 2.0 & 8.3 & 10.6 & 15.6 & 19.6 & 27.9 & 39.0 \\
$\mathrm{La}^{3+}$ & 13.0 & 20.0 & 34.0 & 47.6 & 56.5 & 68.9 & 80.0 \\
$\mathrm{~Pb}^{2+}$ & 1.9 & 2.2 & 4.6 & 10.6 & 23.1 & 30.1 & 42.0 \\
$\mathrm{Fe}^{3+}$ & 80.5 & 100.0 & 140.0 & 220.0 & 333.0 & 400.2 & 450.0 \\
$\mathrm{Al}^{3+}$ & 12.3 & 23.0 & 44.5 & 60.1 & 75.6 & 92.0 & 99.7 \\
\hline
\end{tabular}

Table 5. Separations of metal ions achieved on the column of $\left(\mathrm{HQCR}_{4}\right)$

\begin{tabular}{ccccccc}
\hline $\begin{array}{c}\text { Mix } \\
\text { No. }\end{array}$ & $\begin{array}{c}\text { Metal } \\
\text { ions }\end{array}$ & Eluents mL & $\begin{array}{c}\text { Eluate } \\
\mathrm{mL}\end{array}$ & $\begin{array}{c}\text { Amount } \\
\text { Loaded } \mu \mathrm{g}\end{array}$ & $\begin{array}{c}\text { Amount } \\
\text { found } \mu \mathrm{g}\end{array}$ & $\begin{array}{c}\text { Error } \\
\%\end{array}$ \\
\hline 1. & $\mathrm{Pb}^{2+}$ & $0.1 \mathrm{M} \mathrm{HNO}_{3}$ & 30 & 410 & 412 & +0.49 \\
& $\mathrm{Zn}^{2+}$ & $0.2 \mathrm{M} \mathrm{HNO}_{3}$ & 30 & 327 & 325 & -0.61 \\
2. & $\mathrm{Pb}^{2+}$ & $0.1 \mathrm{M} \mathrm{HNO}_{3}$ & 30 & 410 & 412 & +0.49 \\
& $\mathrm{Th}^{4+}$ & $1 \mathrm{M} \mathrm{HNO}_{3}$ & 40 & 464 & 460 & -0.86 \\
3. & $\mathrm{Ni}^{2+}$ & $0.01 \mathrm{M} \mathrm{HNO}_{3}$ & 30 & 240 & 245 & +2.08 \\
& $\mathrm{Cu}^{2+}$ & $0.1 \mathrm{M} \mathrm{HNO}_{3}$ & 30 & 318 & 312 & -1.87 \\
4. & $\mathrm{Zr}^{4+}$ & $0.2 \mathrm{M} \mathrm{HNO}_{3}$ & 30 & 364 & 365 & +0.27 \\
& $\mathrm{Hg}^{2+}$ & $1 \mathrm{M} \mathrm{HNO}_{3}$ & 40 & 400 & 396 & -1.00 \\
5. & $\mathrm{Al}^{3+}$ & $0.01 \mathrm{M} \mathrm{HNO}_{3}$ & 30 & 270 & 270 & 0.00 \\
& $\mathrm{Fe}^{3+}$ & $0.2 \mathrm{M} \mathrm{HNO}_{3}$ & 50 & 558 & 552 & -1.08 \\
6. & $\mathrm{Ni}^{2+}$ & $0.01 \mathrm{M} \mathrm{HNO}_{3}$ & 30 & 240 & 245 & +2.08 \\
& $\mathrm{Co}^{2+}$ & $0.2 \mathrm{M} \mathrm{HNO}_{3}$ & 40 & 236 & 237 & +0.42 \\
& $\mathrm{Hg}^{2+}$ & $1 \mathrm{M} \mathrm{HNO}_{3}$ & 40 & 400 & 396 & -1.00 \\
7. & $\mathrm{Cd}^{2+}$ & $0.1 \mathrm{NaNO}_{3}$ & 30 & 340 & 342 & +0.59 \\
& $\mathrm{Zn}^{2+}$ & $0.02 \mathrm{M} \mathrm{HNO}_{3}$ & 30 & 327 & 325 & -0.61 \\
& $\mathrm{Cu}^{2+}$ & $0.1 \mathrm{M} \mathrm{HNO}_{3}$ & 40 & 400 & 396 & -1.00 \\
\hline
\end{tabular}

The sorption capacity of various samples of 8-hydroxyquinoline chelating resins $\left(\mathrm{HQCR}_{4}\right)$ given in Table 3 reveal that in the syntheses of HQCR 4 increased amount of 8hydrroxyquinoline results increase sorption capacity as well as yield of the resin. Sample $\mathrm{HQCR}_{4}$ was chosen for further studies owing to its highest sorption capacity maximum yield and good appearance. The physicochemical properties given in Table 2 show that the chelating resin $\mathrm{HQCR}_{4}$ in $\mathrm{H}^{+}$for also behaves as a weak cation exchanger. The results of rate of sorption experiments plotted in Figure 1 reveal that the rate of sorption is high during the initial period of contract time and time required for maximum sorption capacity is $50 \mathrm{~min}$. The fast uptake of metal ions by $\mathrm{HQCR}_{4}$ in the aqueous solutions may be explained on the basis of present 8-hydroxyquinoline a chelating reagent ${ }^{11-16}$. 
The sorption capacities determined for six metal ions in three $\mathrm{pH}$ systems (Table 4) resulted the following order.

$$
\mathrm{Hg}^{2+}>\mathrm{Co}^{2+}>\mathrm{Cd}^{2+}>\mathrm{Zn}^{2+}>\mathrm{Ni}^{2+}>\mathrm{Cu}^{2+}
$$

The sorption was found to increase with the increase in $\mathrm{pH}$, however, the capacity order for the investigated metal ions remained unchanged. The variation in sorption capacities for different metal ions may be explained on the basis of difference in stability of metal 8-HQ complexes under experimental conditions. The results of distribution coefficients determined for thirteen metal ions in different $\mathrm{pH}$ system indicate that $\mathrm{Hg}^{2+} \mathrm{Cu}^{2+}$ and $\mathrm{Fe}^{3+}$ are strongly adsorbed on $\mathrm{HQCR}_{4}$ resign $\mathrm{Th}^{4+}, \mathrm{Zn}^{2+}, \mathrm{Co}^{2+}$ and $\mathrm{Ni}^{2+}$ only partially while $\mathrm{Cd}^{2+} \mathrm{Mn}^{2+}, \mathrm{Zr}^{4+}$ $\mathrm{La}^{3+} \mathrm{Pb}^{2+}$ and $\mathrm{Al}^{3+}$ are scarcely adsorbed. The reason for selective sorption of certain types of metal ions can be attributed to the large difference in the stability constants of metal-8 HQ complexes.

In the FTIR spectrum of $\mathrm{HCQR}_{4}$ (Figure 2), a broad absorption band in the region 3100 - $3400 \mathrm{~cm}^{-1}$ is evident due to O-H stretching in polymeric association. The peak at $2930 \mathrm{~cm}^{-1}$ belongs to $\mathrm{O}-\mathrm{H}$ stretching in chelate compound. The absorption band at $1602 \mathrm{~cm}^{-1}$ seems due to the presence of $\mathrm{C}=\mathrm{N}$ group stretching vibration in the ring. In the spectrum the bonds at 1553, 1503 and $1436 \mathrm{~cm}^{-1}$, are due to aromatic rings. The peaks of $1218 \mathrm{~cm}^{-1}$ seems due to stretching vibration of phenols ${ }^{17-22}$. The results of breakthrough curve (Figure 3) revealed that as many as 58 bed volumes of $\mathrm{Hg}^{2+}$ (corresponding to $116.34 \mathrm{mg}$ retention) can be passed through the chelating resin $\mathrm{HQCR}_{4}$ column without any trace being detected in the effluent. On the other hand in case of resin sample $\mathrm{HQCR}_{4}$ only 20 bed volumes (corresponding to $40.12 \mathrm{mg}$ ) were required to elute $\mathrm{Hg}^{2+}$. The higher breakthrough capacity of $\mathrm{HQCR}_{4}$ may be attributed due (metal-8-HACR ) complex formation. Similarly for $\mathrm{HQCR}_{4}$ breakthrough for $\mathrm{Co}^{2+}$ and $\mathrm{Zn}^{2+}$ occurs after 55 and 40 bed volumes (corresponding to 32.41 and $26.16 \mathrm{mg}$ ) respectively.

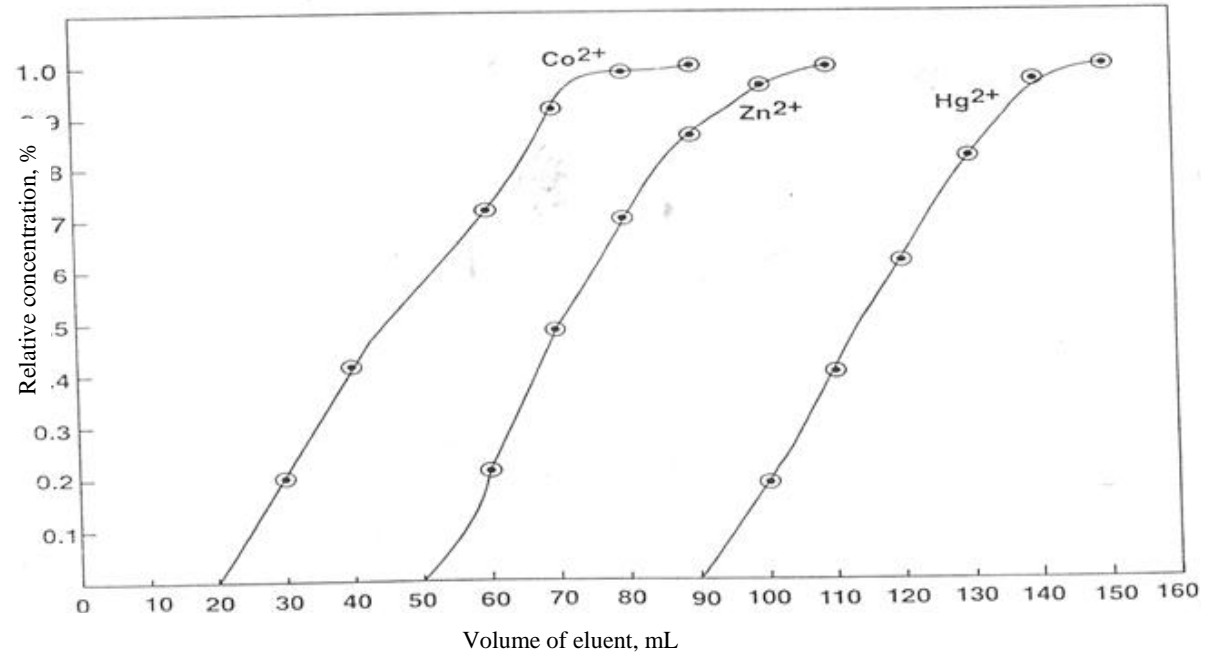

Figure 3. Breakthrough curves of different metal ions

On the basis of large difference in $K_{d}$ values, separations were tried and experimentally successful results are reported in Table 5 . It is interesting to note that no significant tailing was obtained during the elution various metal ions and only small volume of eluent were required to give compact chromatograms Figure (4-10). 


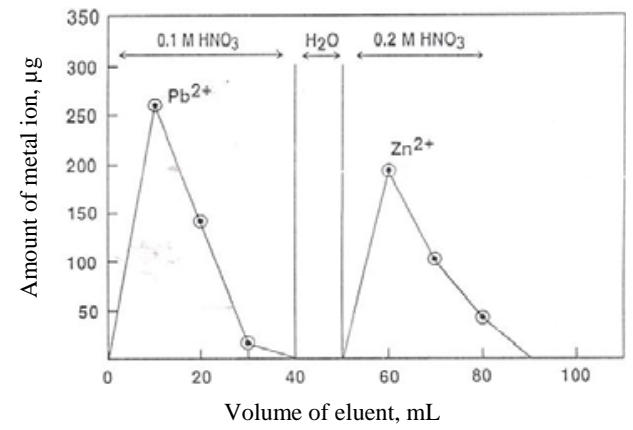

Figure 4. Separation of $\mathrm{Pb}^{2+}-\mathrm{Zn}^{2+}$

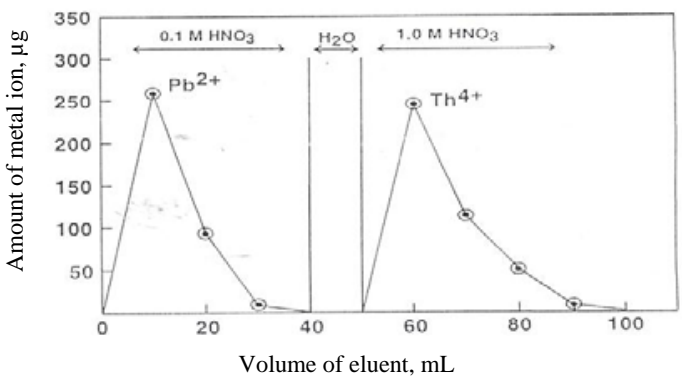

Figure 5. Separation of $\mathrm{Pb}^{2+}-\mathrm{Th}^{4+}$

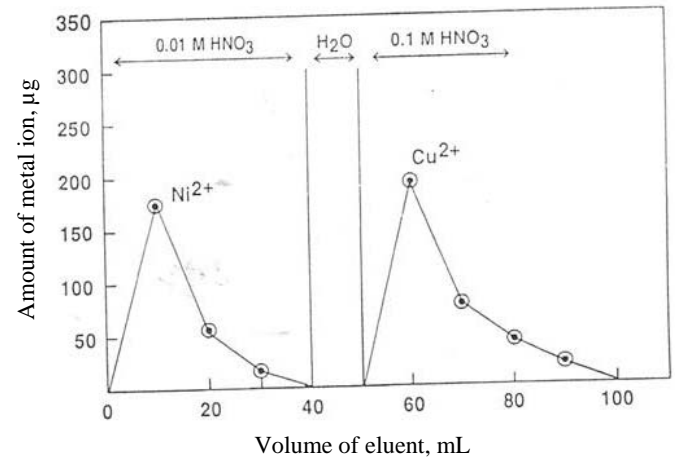

Figure 6. Separation of $\mathrm{Ni}^{2+}-\mathrm{Cu}^{2+}$

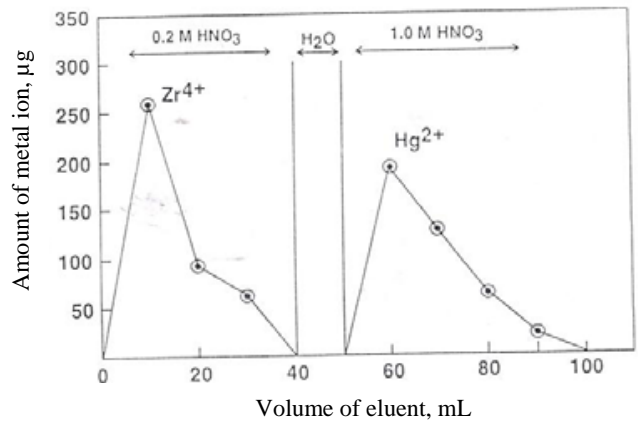

Figure 7. Separation of $\mathrm{Zr}^{4+}-\mathrm{Hg}^{2+}$ 


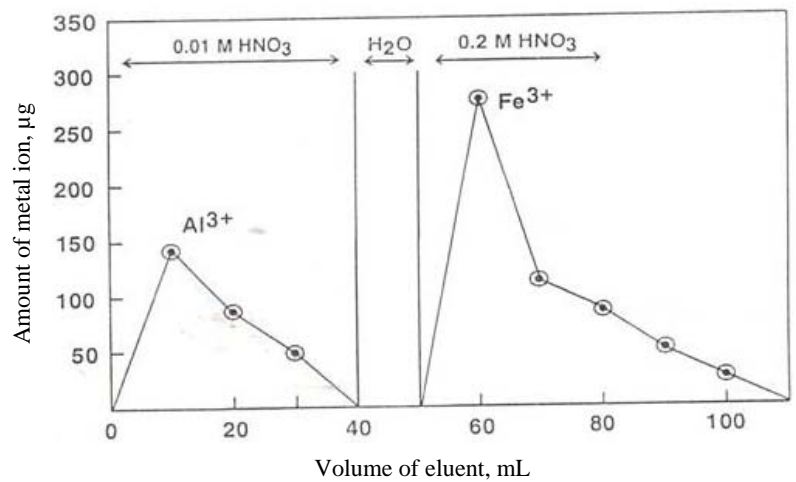

Figure 8. Separation of $\mathrm{Al}^{3+}-\mathrm{Fe}^{3+}$

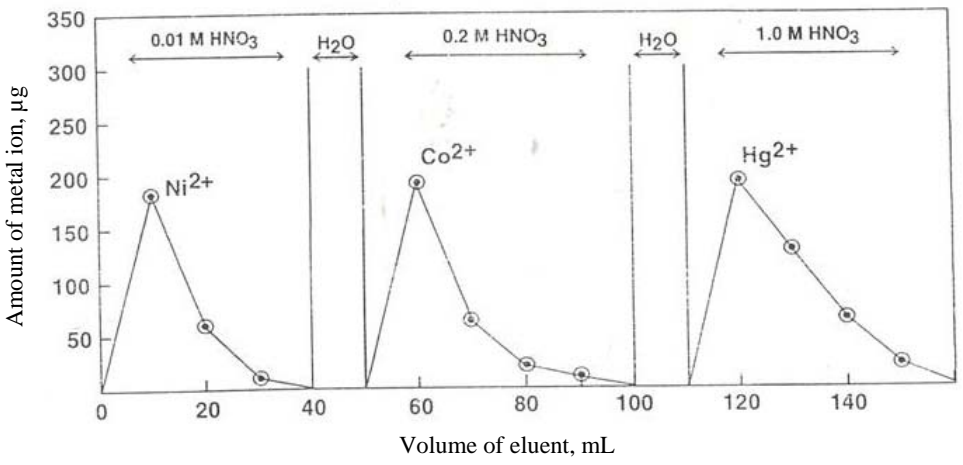

Figure 9. Separation of $\mathrm{Ni}^{2+}-\mathrm{Co}^{2+}-\mathrm{Hg}^{2+}$

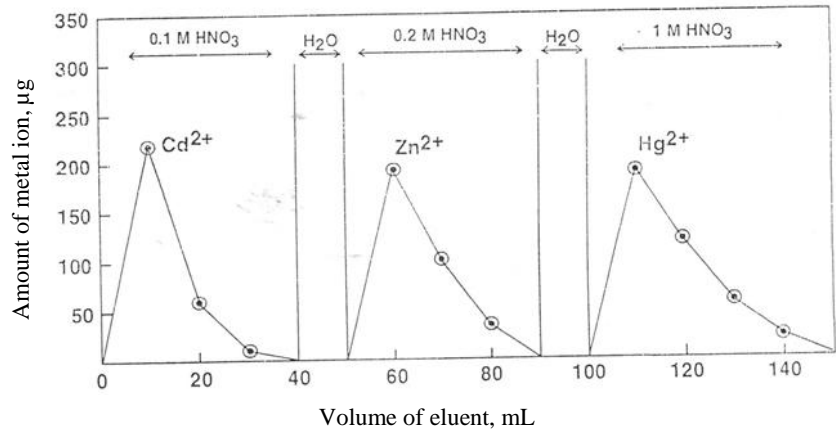

Figure 10. Separation of $\mathrm{Cd}^{2+}-\mathrm{Zn}^{2+}-\mathrm{Hg}^{2+}$

\section{Conclusion}

The single-step attachment of 8-hydroxyquinoline as ion exchange resin represents a significant improvement over the previously published method, and will be of benefit to the many marine chemists utilizing this sort of resin for concentrating trace transitional metals from seawater in various applications.

\section{References}

1. Wegscheider W and Knapp G, Crit Rev Anal Chem., 1981, 11, 79. 
2. Sherrington D C and Hodge P, Synthesis and Separation using Functional Polymers, Willey, New York, 1988.

3. Blasius E and Brozio R C, Chelates in Analytical Chemistry, Flaschka H A and Barnard J A, Eds., Marcel Dekker, New York, 1967, 50.

4. Pittman C V, Hodge P and Sherrington D C, Jr. Polymer Supported Reactions in Organic Synthesis, Wiley, New York, 1980.

5. Collman J P, Gange R R, Kouba J and Ljusberg H Wohren, J Am Chem Soc., 1974, 96(21), 6800-6802; DOI:10.1021/ja00828a064

6. $\quad$ Pittman C V and Ng Q, J Organomet Chem., 1978, 153(1), 85-97; http://dx.doi.org/10.1016/S0022-328X(00)90935-5

7. Shah B A, Shah A V and Bhandari B N, Asian J Chem., 2001, 13(4), 1305-1311.

8. $\quad$ Saito T and Torii S, Sep Sci Technol., 2002, 37(1), 77-87.

9. Syamal D Kumar, Singh A K, Gupta P K, Pal J and Sharma L K, Indian J Chem., 2002, 41, 1385-1390.

10. $\quad$ Nguyen P M and Hammond P T, Langmuir, 2006, 22(18), 7825-7832;

DOI:10.1021/la0607050

11. Kim T, Seo H J, Choi J S, Jang H S, Baek J, Kim K and Ong-Sang Park, Biomcromolecules, 2004, 5(6), 2487-2492; DOI:10.1021/bm049563j

12. Duan X, Yuan F, Wen X, Yang M, He B and Wang W, Macromol Chem Phys., 2004, 205(10), 1410-1417; DOI:10.1002/macp.200400055

13. Namazi H and Adeli M, Polymer, 2005, 46(24), 10788-10799; http://dx.doi.org/10.1016/j.polymer.2005.09.020

14. Namazi H and Adeli M, J Polym Sci Part A Polym Chem., 2005, 43(1), 28-41; DOI: $10.1002 /$ pola.20471

15. Wang D, Liu Y, Hu Z C, Hong C Y and Pan C Y, Polymer, 2005,,46(10), 3507-3514; http://dx.doi.org/10.1016/j.polymer.2005.02.095

16. Wang D, Liu Y, Hong C Y and Pan C Y, Polymer, 2006, 47(11), 3799-3806; http://dx.doi.org/10.1016/j.polymer.2006.03.088

17. Wang D, Zheng Z J, Hong C Y, Liu Y and Pan C Y, J Polym Sci Part A Polym Chem., 2006, 44(21), 6226-6242; DOI:10.1002/pola.21716

18. Adeli M, Zarnegar Z, Dadkhah A, Hossieni R, Salimi F and Kanani A, J Appl Polym Sci., 2007, 104(1), 267-272; DOI:10.1002/app.25583

19. Ge Z S, Chen D Y, Zhang J Y, Rao J Y, Yin J, Wang D, Xuejuan Wan, Wenfang Shi and Shiyong Liu, J Polym Sci Part A Polym Chem., 2007, 45(8), 1432-1445; DOI: 10.1002/pola.21914

20. Lai P S, Lou P J, Peng C L, Pai C L, Yen W N, Huang M Y, Tai-Horng Young and Ming-Jium Shieh. J Controlled Release, 2008, 12(1), 39-46; http://dx.doi.org/10.1016/j.jconrel.2007.06.012

21. Shi X, Thomas T P, Myc L A, Kotlyar A and Bake J R, Phys Chem Chem Phys., 2007, 9, 5712-5720; DOI:10.1039/B709147H

22. Iyer J, Fleming K and Hammond P T, Macromolecules, 1998, 31(25), 8757-8765; DOI:10.1021/ma980654g 